\title{
A Statistical Study on the Impact of Rain Water Harvesting on Groundwater Levels and Farming Economy
}

\author{
K.S. Shwetha*, K.V. Ashalatha, A.R.S. Bhat and Tanveer Ahmed Khan
}

Department of Agricultural Statistics, College of Agriculture, UAS, Dharwad, India - 580005

*Corresponding author:

\section{A B S T R A C T}

\section{Keywords}

Rainwater harvesting, Correlation, Backward regression, t-test, cropping intensity, $\mathrm{B}: \mathrm{C}$ ratio etc.

Article Info

Accepted: 10 March 2019 Available Online: 10 April 2019
The present investigation was carried out in Dharwad Taluk (Karnataka) during 20072008 , to evaluate the influence of weather parameter on ground water level and the impact of Rain Water Harvesting on farming economy. Monthly data on weather parameters and ground water level recorded by District Statistical Office, Main Research Station Dharwad and Department of Mines and Geology Dharwad respectively for 28 years were collected. Primary data were collected from the randomly selected 60 sample farmers of both with and without Rain Water Harvesting Systems. Data related to year 2007-2008 were elicited using pre-structured and pre-tested schedules. The results of the analysis indicated that the ground water was significantly correlated with rainfall (positively) and temperature (negatively). The study indicated that the farmers of with RWHS were found to have positive impact on land holding, cropping intensity. Investment of farmers of with RWHS indicated favorable results in terms of $\mathrm{B}$ : $\mathrm{C}$ ratio.

\section{Introduction}

Water is an essential and precious resource upon which our ecosystem and agriculture production depend. However, water a natural resource of the world, constitutes 1,384 million cubic kilometers of which around 97.39 per cent (i.e. 1,348 million cubic kilometers) is in the oceans. Another 2.61 per cent (i.e., 36 million $\mathrm{km}^{3}$ ) is fresh water of this 77.23 per cent $\left(27.82\right.$ million $\left.\mathrm{km}^{3}\right)$ is in polar ice caps, icebergs and glaciers. Only small fraction of water resources $(0.59 \%$ or 8.2 million $\mathrm{km}^{3}$ ) of the earth is present in the ground, lakes, rivers and atmosphere and is useful to mankind. Whereas, more than 99 per cent of water present on the earth is not useful to agriculture (Anonymous, 2003).

Mounting population pressure, increasing concerns of food and nutrition security and environmental safety make natural resources management a key strategy towards achieving sustainability in dry land agriculture. Rainfed agriculture contributes about 44 percent of the total food grain production in the country and supports 40 percent of the population (Chandracharan et al., 2007). Rainwater is the 
essential input in dry land agriculture. Rainfall is the principle source of replenishment of moisture in the soil through infiltration process and subsequent recharge to the ground water through deeper percolation. In India, approximately 24 million hectare meter equivalent runoff is available for harvesting and many indigenous and improved water harvesting practices are available to utilize the runoff. From the above facts it is evident that there is a considerable scope to undertake a statistical impact study of rain water harvesting. Even though Sujala watershed efforts at farm level water harvesting schemes are wide spread in Karnataka, the impact is not fully explored. Due to this reason the present study was designed with the objective to know the impact of weather parameter on ground water levels and rain water harvesting structures on economy of the farmers.

\section{Materials and Methods}

The required data for the present study included both secondary and primary data. Secondary data on weather parameters viz., rainfall, relative humidity $(\mathrm{RH})$, wind speed and temperature were collected from District Statistical Office (DSO) and Main Research Station (MRS) Dharwad. The data on ground water level was collected from Department of Mines and Geology, Dharwad. Monthly data on weather parameters and ground water level for 28 years were collected. The primary data on household compositions, land holdings, cropping pattern, social behavior etc were collected from the randomly selected 60 sample farmers of both with and without RWHS. Primary data related to agriculture year 2007-2008 in Managundi and Mansur sub watersheds of Dharwad taluk were elicited using prestructured and pre tested schedules.

The degree of relationships between ground water level and each of the weather parameters viz., rainfall, relative humidity, wind speed and temperature were determined by using Karl Pearson's correlation coefficient. Coefficient of determination $\left(\mathrm{R}^{2}\right)$ is used as the measure of explanatory value of the model. Based on the $\mathrm{R}^{2}$, model of best fit to the data was selected. In case of multiple regressions, ground water level was considered as dependent variable and independent variables were rainfall, relative humidity, wind speed and temperature. To determine the contribution of each independent variable to the ground water level, backward regression technique was carried out, where the variables which contribute least to the dependent variable are eliminated one by one. Statistical packages like SPSS 15.0 and curve expert were used for correlation and regression analysis. To compare the socio economic features of the farmers with and without RWHS the two sample independent t-test is carried out to test the null hypotheses on land holdings. The paired t test was used to analyze the impact of rain water harvesting structures on productivities of major crops among sample farmers. Impact of RWHS on Cropping intensity was calculated to measure the intensity of cropping in time and space dimensions i.e. in case of mono cropping CI is always $100 \%$ and in case of multiple cropping it is more than $100 \%$ (Arun Katyayan, 2001). The benefit cost ratio of the cropping pattern of the sample farmers was analysed to compare the gross benefits to the total costs to determine the economical condition of the sample farmers.

\section{Results and Discussion}

\section{Impact of weather parameters on ground water level}

Correlation coefficient between ground water level and different weather parameters were calculated which is presented in Table 1 in the form of correlation matrix. The ground water 
level was significant and positively correlated with rainfall (0.618) and was negatively correlated with temperature (-0.401). Rest of the parameters i.e. relative humidity and wind speed were not significantly correlated with ground water level with correlation coefficient 0.348 and 0.237 respectively. The results of the correlation analysis of weather parameter and ground water level gain support from the study conducted by Muralidharan et al., (2007), who observed that rise in water level yielded an exponential relation indicating that daily rainfall exceeding $40 \mathrm{~mm} /$ day results in significant rise in ground water level.

The multiple regression model fit was found highly significant $(1 \%)$ for the data with $\mathrm{R}^{2}=0.44$. The results are presented in Table 2 and coefficient of significance is presented in Table 3. Out of the four weather parameters only rainfall was contributing significantly to ground water level. Even though temperature was contributing significantly when taken individually, in presence of other variable it was not found significant. The result was in conformity with the findings of Sreekanth (2009), who reported that, a reliable forecasting model for predicting the ground water level using weather parameter through ANN (Artificial Neural Network) was proved to be the best fit with $\mathrm{R}^{2}=0.93$.

The contribution of each weather parameters to the ground water level using backward regression technique is presented in Table 4. Regression model for predicting the ground water level based on rainfall was found better by eliminating the other variables i.e, wind speed, relative humidity, temperature one by one. In this model only rainfall was retained which is contributing to the ground water level and $\mathrm{R}^{2}$ was found to be 0.38 (Fig. 1). This indicates that rainfall plays a major role in predicting ground water level followed by temperature.

\section{Impact of Rain Water Harvesting systems on farming economy}

Majority of the farmers belonged to large farmers category (Table 5) in case of with RWHS(63.33\%) and without RWHS (46.67\%) followed by small farmers. The average land holdings observed was almost same (2.54 ha and 2.02 ha) in both areas. The difference in the land holding of the farmers of both adopters and non-adopters group was found not significant. The land holdings of the farmers before and after adoption of RWHS were compared an the difference in land holding was found highly significant (1\%) (Table 6). This indicates that the area of cropping or the increase in yield in case of either of the group is due to impact of RWHS not because of land holdings or the farmers brought more area under cultivation after adopting the RWHS because of the availability of moisture even in the rabi season. This study conformed to earlier findings by Jahagirdar (1991), who observed that during 1985-86 to 1990-91, the cultivated area of the farmers belonging to watershed area increase in both Kharif and rabi season.

It is evident from the Table 7 that the gross cropped area was more in case of with RWHS (104.36 ha) area compared to without RWHS (64.8 ha) area mainly because of better conservation residual moisture in the rabi season due to construction of RWHS. As a result cropping intensity enhanced (128.09\%) in case of RWHS area. The results gain support from the study conducted by Neema et al., (1991) Desai et al., (2007) and other who observed that the adoption of in situ moisture conservation technique has resulted in decline of the area under waste land and helps in increasing the cropping intensity.

The results presented in Table 8 revealed better idea about the differences in crop productivities of various crops of with and without RWHS areas by virtue of 
implementation of RWHS. The net crop yield in with RWH area over without RWH area was more in case of paddy $(7.05 \mathrm{q} / \mathrm{ha})$ followed by maize $(6.23 \mathrm{q} / \mathrm{ha})$ and soybean $(5.16 \mathrm{q} / \mathrm{ha})$ with percentage change of $40.17 \%, 28.29 \%$ and $36.41 \%$ respectively. It could be inferred that percentage increase of crop productivity obtained by the farmers with RWHS was considerably higher over without RWHS area. The result is in conformity with the findings of Singh and Rahim (1990) and Chandracharan et al., (2007) reported that due to increased soil moisture and increased area under kharif and rabi that positively lead to increase in the crop yields.

Table.1 Correlation between the Ground water level and weather parameters

\begin{tabular}{|c|c|c|c|c|c|}
\hline Parameters & $\begin{array}{c}\text { Ground } \\
\text { Water level }\end{array}$ & Rainfall & $\begin{array}{l}\text { Relative } \\
\text { Humidity }\end{array}$ & Wind Speed & Temperature \\
\hline $\begin{array}{c}\text { Ground Water } \\
\text { level }\end{array}$ & 1 & $\begin{array}{l}0.618 * * \\
(0.000)\end{array}$ & $\begin{array}{c}0.348 \\
(0.069)\end{array}$ & $\begin{array}{c}0.237 \\
(0.225)\end{array}$ & $\begin{array}{c}-0.401 * \\
(0.034)\end{array}$ \\
\hline Rainfall & & 1 & $\begin{array}{c}0.258 \\
(0.185)\end{array}$ & $\begin{array}{c}0.242 \\
(0.215)\end{array}$ & $\begin{array}{l}-0.311 \\
(0.107)\end{array}$ \\
\hline $\begin{array}{l}\text { Relative } \\
\text { Humidity }\end{array}$ & & & 1 & $\begin{array}{c}0.112 \\
(0.570)\end{array}$ & $\begin{array}{c}0.586 * * \\
(0.001)\end{array}$ \\
\hline Wind Speed & & & & 1 & $-0.145(0.463)$ \\
\hline Temperature & & & & & 1 \\
\hline
\end{tabular}

Table.2 ANOVA for multiple regression

\begin{tabular}{|l|c|c|c|c|c|}
\hline $\begin{array}{l}\text { Sources of } \\
\text { variation }\end{array}$ & df & $\begin{array}{c}\text { Sum of } \\
\text { squares }\end{array}$ & $\begin{array}{c}\text { Mean sum of } \\
\text { squares }\end{array}$ & F & Significance \\
\hline Regression & 4 & 70.48 & 17.62 & 4.35 & 0.009 \\
Residual & 23 & 92.97 & 4.04 & & \\
Total & 27 & 163.46 & & & \\
\hline
\end{tabular}

Table.3 Model summary for multiple regressions

\begin{tabular}{|l|c|c|c|}
\hline \multirow{2}{*}{ Variables } & \multicolumn{2}{|c|}{ Co-efficient } & t \\
\hline Constant & B & SE & . \\
Rainfall & 24.15 & $\mathbf{3 9 . 4 2}$ & $\mathbf{2 . 9 8 0}$ \\
Relative humidity & $0.07 * *$ & $\mathbf{0 . 0 0 2}$ & $\mathbf{0 . 5 3 5}$ \\
Wind speed & 0.04 & $\mathbf{0 . 0 7 6}$ & $\mathbf{0 . 5 3 6}$ \\
Temperature & 0.19 & $\mathbf{0 . 3 5 8}$ & $\mathbf{0 . 7 3 3}$ \\
\hline
\end{tabular}

** Significance at $1 \%$; Dependent variable is Ground water level

Multiple regression equation for ground water level and weather parameter

$\mathrm{Y}=24.15+0.007 * * \mathrm{X}_{1}+0.04 \mathrm{X}_{2}+0.19 \mathrm{X}_{3}-1.057 \mathrm{X}_{4}$ with $\mathrm{R}^{2}=0.44$
X1: Rainfall;
X2: Relative humidity

X3: Wind speed;

X4: Temperature 
Table.4 Backward regression model for ground water level and weather parameter

\begin{tabular}{|l|c|c|l|l|}
\hline Model & Variables Entered & Variables Removed & $\mathbf{R}^{\mathbf{2}}$ & Significance \\
\hline Start & Temp, WS, RF, RH & - & 0.44 & 0.007 \\
\hline $\mathbf{1}$ & Temp, RF, RH & WS & 0.43 & 0.003 \\
\hline $\mathbf{2}$ & Temp, RF & WS, RH & 0.43 & 0.001 \\
\hline $\mathbf{3}$ & RF & Temp, WS, RH & $\mathbf{0 . 3 8}$ & $\mathbf{0 . 0 0 0 4 5}$ \\
\hline
\end{tabular}

Table.5 Classification of sample farmers according to their land holdings

\begin{tabular}{|c|c|c|c|c|c|}
\hline \multirow[b]{2}{*}{ Sl.no } & \multirow[b]{2}{*}{ Farmer's type } & \multicolumn{2}{|c|}{ With RWHS } & \multicolumn{2}{|c|}{ Without RWHS } \\
\hline & & Frequency & Percentage & Frequency & Percentage \\
\hline 1. & Marginal ( < 1 hectare) & 2 & 6.67 & 3 & 10.00 \\
\hline 2. & Small (1 to 2 hectares) & 9 & 30.00 & 13 & 43.33 \\
\hline 3. & Large (> 2 hectares) & 19 & 63.33 & 14 & 46.67 \\
\hline 4. & Total & 30 & 100.00 & 30 & 100.00 \\
\hline 5. & Average land holding (ha) & \multicolumn{2}{|c|}{2.54} & \multicolumn{2}{|c|}{2.02} \\
\hline
\end{tabular}

Table.6 Comparison of the land holdings and impact of RWHS on beneficiaries and nonbeneficiaries

\begin{tabular}{|c|c|c|}
\hline \multirow{2}{*}{ Particulars } & \multicolumn{2}{|c|}{ After adoption of RWHS } \\
\cline { 2 - 3 } & Mean \pm sd & t-value \\
\hline Non adopters & $2.02 \pm 0.86$ & $1.52^{\mathrm{NS}}$ \\
Non adopters & $2.54 \pm 1.66$ & $4^{* * 85^{* *}}$ \\
Before RWHS & $2.02 \pm 1.47$ & \\
After RWHS & $2.54 \pm 1.66$ & \\
\hline
\end{tabular}

NS: Non significance; **Significant at $1 \%$

Table.7 Impact of RWHS on cropping intensity of the sample farmers

\begin{tabular}{|l|c|c|}
\hline \multicolumn{1}{|c|}{ Particulars } & With RWHS & Without RWHS \\
\hline $\begin{array}{l}\text { Gross cropped area } \\
\text { (hectares) }\end{array}$ & 104.36 & 64.8 \\
$\begin{array}{l}\text { Net cropped area } \\
\text { (hectares) }\end{array}$ & 81.47 & 60.64 \\
Cropping intensity (\%) & 128.09 & 106.86 \\
\hline
\end{tabular}


Table.8 Impact of rain water harvesting on productivities of major crops

(Q/hectares)

\begin{tabular}{|l|c|c|c|}
\hline \multicolumn{1}{|c|}{ Crops } & With RWHS & Without RWHS & $\begin{array}{c}\text { \% Change in crop yield over without RWHS } \\
\text { area }\end{array}$ \\
\hline Paddy & 24.60 & 17.55 & $\mathbf{7 . 0 5}(\mathbf{4 0 . 1 7})$ \\
Maize & 28.25 & 22.02 & $\mathbf{6 . 2 3}(\mathbf{2 8 . 2 9})$ \\
Jowar & 16.75 & 12.83 & $3.92(30.55)$ \\
Soybean & 19.33 & 14.17 & $\mathbf{5 . 1 6}(36.41)$ \\
Cotton & 15.34 & 11.25 & $\mathbf{4 . 0 9}(36.35)$ \\
Ground nut & 16.63 & 13.50 & $\mathbf{3 . 1 3}(\mathbf{2 3 . 1 8})$ \\
Horse gram & 6.52 & 4.34 & $\mathbf{2 . 1 8}(\mathbf{5 0 . 2 3})$ \\
Green gram & 4.89 & 3.33 & $\mathbf{1 . 5 6 ( 4 6 . 8 4 )}$ \\
\hline
\end{tabular}

Figures in parentheses indicates percentages to total

Table.9 Cost and return profile of the crops of sample farmers

\begin{tabular}{|l|c|c|}
\multicolumn{2}{|c|}{ (Rs. Per Ha) } \\
\hline Sl.No & With RWHS & Without RWHS \\
\hline Total gross returns & $\mathbf{1 4 0 4 8 . 0 8}$ & $\mathbf{1 0 2 4 7 . 3 6}$ \\
Total cost & $\mathbf{6 6 8 3 . 4 4}$ & $\mathbf{6 7 2 7 . 5 7}$ \\
B:C ratio & $\mathbf{2 . 1 0}$ & $\mathbf{1 . 5 2}$ \\
\hline
\end{tabular}

Fig.1 Diagrammatic representation of the important characters and r2 value included in backward regression model

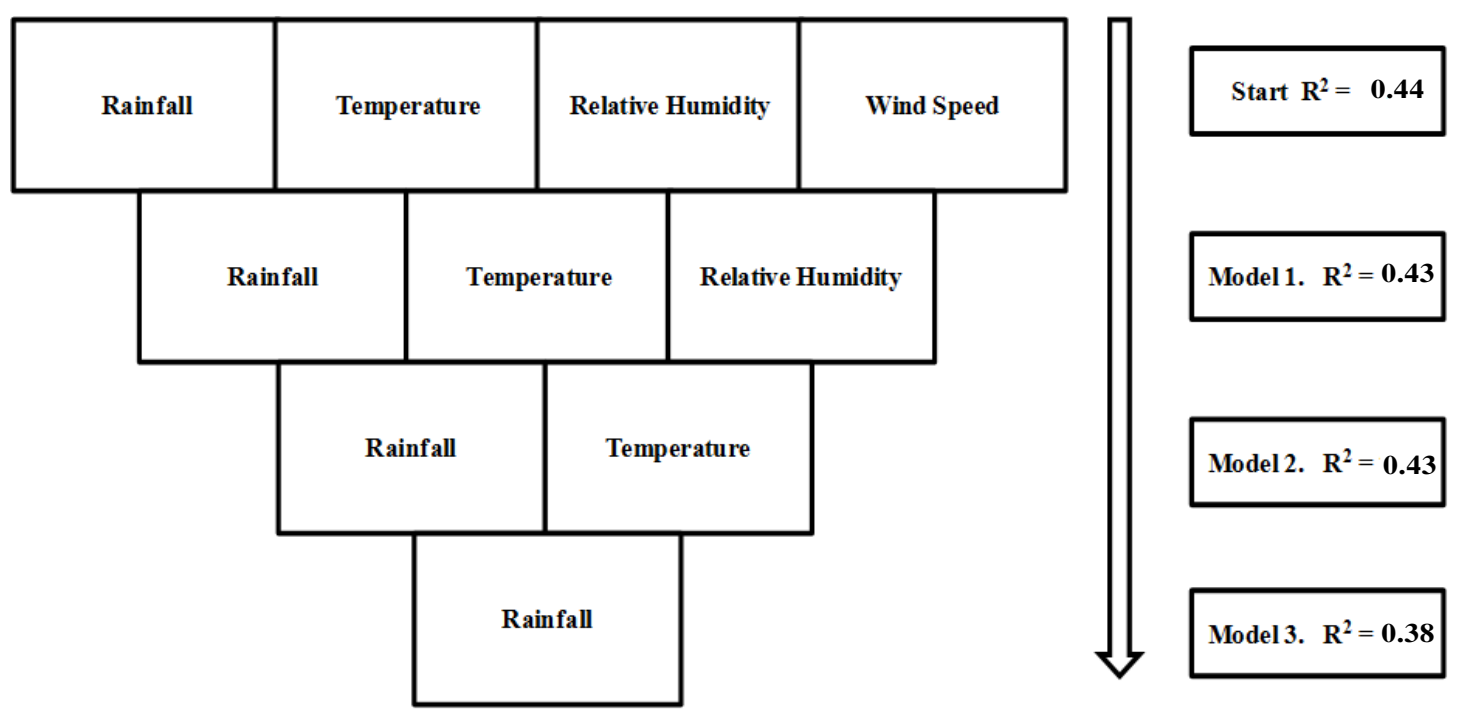

A critical observation of cost and returns structure (Table 9) revealed that the cost of cultivation was more in case of without RWHS area. However, returns were more in case of with RWHS area as compared to without RWHS area. The B:C ratio was more than unity in both the cases. But the returns per rupee of cost were observed more for the farmers of with RWHS as compared to farmers of without RWHS. The above findings were supported by the study conducted by Naidu (2001), Singh and Gupta (1991), who noticed that the watershed projects gave positive net returns throughout the period. 


\section{Policy implication}

The prediction model showed the positive and similar trends in groundwater level and rainfall. This response will be higher in watershed areas where water is continuously available for groundwater recharge till the pond becomes dry. Therefore in order to increase the groundwater recharge and moisture conservation, farmers need to be encouraged to follow the adoption of rainwater harvesting structures under watershed technology. Watershed technology has helped in augmenting returns from dryland agriculture. RWHS were found to have positive impact on cropping intensity, productivity, favourable returns in terms of $\mathrm{B}: \mathrm{C}$ ratio. Hence farmers need to be encouraged to follow this technology particularly in the areas where ground water level has declined.

\section{References}

Anonymous, 2003, National water policy of water resource. Government of India New Delhi, www.watermgmt.com/ en/index.htm.

Arun Katyayan., 2001, Fundamentals of agriculture. Vol-.1. Kushal Publications and Distributors, Varanasi.

Chandracharan, V., Syed Sadaqath., Hirevenkanagoudar, Chandargi, D M., 2007, Adoption of watershed practices by the repsondents of Sujala watershed. Karnataka J. Agric.Sci.,20(1):176-177.

Desai Rajeshwari., Patil., B. L., Kunnal, L.B., Jayashree, H. Basavaraj, H., 2007, Impact assessment of farm-ponds in Dharwad district of Karnataka.
Karnataka J. Agric. Sci., 20 (2):426427.

Jahagirdar, D V., 1991, Manoli watershed development project - A case study of some growth parameters. Indian J. of Agric. Econ., 46 (3): 304.

Muralidharan, D., Rolland Andrade., Rangarajan. R., 2007, Evaluation of check-dam recharge through water-table response in ponding area. Curr.sci., 92 (10): 1350-1352.

Naidu, A., 2001, Evaluation of land and water resources and socioeconomic impact assessment of Vanjuvankal watershed in Ananthpur district of Andhra Pradesh, India. Environment and People, 8(1): 37.

Neema, M.G., Singh, V.N. and Mishra, B.L., 1991, Impact of Barkheda - Hat Watershed development Programme in district of Guna of Madhya Pradesh. Indian J. Agric. Econ., 46(3): 305-306.

Singh, B. V., and Gupta, D. D., 1991, Impact of watershed based farming system on crop productivity and socio-economic status- A case study of Bunga project, Haryana. Indian Journal of Agricultural Economics, 46(3): 304 - 305.

Singh, K. and Rahim, K.M.B., 1990, Identification and evaluation of optimal cropping system for a typical watershed in Uttar Pradesh hills. Indian J. Agric. Econ.,, 45(1): 29-35.

Sreekanth, P. D., Geethanjali, N., Sreedevi, P. D., Shakeel Ahmed, Ravi Kumar, N., and Kamala Jayanthi, P.D., 2009, Forecasting Groundwater level using artificial neural networks. Curr. Sci., 96(7): 933-939.

\section{How to cite this article:}

Shwetha, K.S., K.V. Ashalatha, A.R.S. Bhat and Tanveer Ahmed Khan. 2019. A Statistical Study on the Impact of Rain Water Harvesting on Groundwater Levels and Farming Economy. Int.J.Curr.Microbiol.App.Sci. 8(04): 906-912. doi: https://doi.org/10.20546/ijcmas.2019.804.104 